\title{
IAMJ
}

INTERNATIONAL

AYURVEDIC

MEDICAL JOURNAL

ISSN: 23205091

Impact Factor: 5.344

\section{MODIFIED KSHARSUTRA TECHNIQUE IN COMPLEX FISTULA IN ANO - A CASE STUDY}

\section{$\underline{\text { Rashmi Gupta }}$}

Assistant Professor, Dept. of Shalya Tantra, Faculty of Ayurvrda, IMS, BHU Varanasi, 221005, Uttar Pradesh, India

Corresponding Author: drrashmiguptabhu@gmail.com

\section{https://doi.org/ $10.46607 /$ iamj6308102020}

(Published online: October 2020)

Open Access

(C) International Ayurvedic Medical Journal, India 2020

Article Received: 11/07/2020 - Peer Reviewed: 27/08/2020 - Accepted for Publication: 10/09/2020

(D) Check for updates

\section{ABSTRACT}

Fistula in ano is an anorectal disorder in which two openings are present. One is located near perianal region and another is at anal canol or rectum. Fistula in ano is itself a challenging disease for patients because of mortality is not associated but daily routine life of patients become crushed. Ayurveda also said about Bhagandar (fistula in ano) that it is Kashta Shadhya Vyadhi i.e. difficult to treat because its take time and recurrence rate is also associated. But Ayurveda has described the Kshar sutra therapy for the treatment of fistula in ano which have high success rate, but time taken. With time, revolution has also come in Ayurvedic treatment modalities for anorectal fistulas. A modified Ksharsutra technique is new technique for treatment of complex fistula in ano. The name of this technique is interception of fistulous tract and application of Ksharsutra (IFTAK). This technique has high success rate with minimal complication, early recovery and there is no recurrence is associated. Cosmetically, this technique is good.

Keywords: Ksharsutra, Fistula in ano, IFTAK, Bhagandar etc.

\section{INTRODUCTION}

In Ayurveda, Bhagandar (Fistula in Ano) is disease which occurs in Anorectal Region. It explains in throughout classical text but importance of Bhagandar
(Fistula in Ano) was first relied by Acharya Sushruta (1500-1000B.C.) father of Indian Surgery. He is also mentioned Bhagandar (Fistula in Ano) is one of the 
Mahagadal ${ }^{l}$ He is given elaborate description of Bhagandar (Fistula in ano) i.e. Nidan (Cause), Samprapti (pathogenesis), Types, Lakshanas (Characteristic features), Upadrava (Complication) and its Chikitsa (Management) of Bhagandar (Fistula in Ano) $)^{2}$. Fistulain-ano has been an anorectal disorder with hassle of pathology to both patient and physician throughout surgical history. Fistula in Ano can be defined as the chronic granulating tract which has two opening primary one opens into anal canal $\&$ another one secondary opening opens skin of perianal region ${ }^{3}$. Unfortunately, the treatment of this disease is not too simple. There are many hazards problems face to surgeon during the course of treatment like Recurrence, incontinence, wound healing, long duration of treatment even that some time the problem of patient still persists or worse than before. Even this changes the different modalities of treatment in fistula in ano time to time such a fistulotomy, fistulectomy, fistulectomy with primary closure, fibrin glue, anal fistula plug, stem cells, VAAFT, Seton, LIFT etc but nobody can be satisfied with its or overcome with complication like incontinence, recurrence, long duration of treatment, wound healing problems and prolonged hospitalization etc. Even till date Fistula in ano treatment is challenging to most of surgeons. The ancient Indian surgeon Sushruta (1500-1000 b.c.) has mentioned use of Ksharsutra ${ }^{4}$ for the treatment of Bhagandar or Nadivrna. Sushruta has described the sign and symptoms and surgical operation in detail in Bhagandar chapter in Sushruta Samhita, Nidan Sthana \& Chikitsa Sthana. The description of Ksharsutra preparation is not mentioned in Sushruta but detail preparation in Chakrapani with the classical reference has given.

Case Report: A 50 year old married male patient, a teacher by profession, has come in Shalya Tantra OPD, NRC-BHU (National Resource Centre of Ksharsutra$\mathrm{BHU}$ ) with the complaints of multiple openings in perianal region and scrotal region with pus discharge and intermittent pain since 6month. Patient have no other medical problem like Hypertension, Diabetes mellitus etc. 2 year back he had similar complaints of pain in the anal region and scrotum associated with pus discharge which was diagnosed as fistula in ano with scrotal extension. Patients was under treatment of another surgeon and underwent for fistulectomy. Patient was operated two times at interval of 6 month in private sector. But still patient has suffered same problem. He noticed pus discharge from perianal region and scrotum. Then he came to Shalya NRC OPD of SSH (Sir Sunder Lal Hospital), BHU for treatment of fistula in ano.

On Examination: On examination scar of previous surgery seen at scrotal region and left side perianal region. There were two openings seen at scrotal region \& two openings at perianal region (one at right side with dimple of skin and second at left side with previous surgical scar marks). On inspection, multiple openings were noted on the perianal region. One external opening on the left side with previous surgical scar mark at 2 o' clock and other opening at right side with dimple of perianal skin. On scrotal two openings were seen with previous surgical scar marks. (see Figure-1). On palpation, there was marked induration associated with tenderness. On digital and proctoscopic examination, tenderness was present at posterior. There was internal opening noted at 6 O'clock position. It was diagnosed as Recurrent Horse-Shoe fistula with scrotal extension but for further confirmation patient was advised for MRI-Fistulogram. MRI suggested a left complex perianal fistula is seen with two branching tracts- one going medially and superiorly with high suprapubic extension resulting in contrast opacification of rectum and another ending blindly in left sided of perianal region.

Aim and Objective - To evaluate the effect of Modified Ksharsutra therapy i.e. IFTAK (Interception of fistulous tract and application of Ksharsutra) in Recurrent complex fistula in ano. Guggulu Ksharsutra has been used for treating recurrent complex fistula in ano.

Plan of Surgery in Recurrent Complex Fistula in Ano-The patient was admitted in Sir Sundar Lal Hospital, BHU Varanasi (SSH-BHU) in under the IPD of Shalya Tantra Male ward, where the following preparation has to start for patient operation.

Pre-Operative Procedure- All Routine Blood (CBC, CT, BT, Blood Urea, fasting blood sugar and Post prandial blood sugar) and urine (Urine routine microscopic) Investigation were done. Along with this all viral 
markers like HIV, HbsAg, HCV were done before the surgery. This patient had recurrent fistula in ano because he was operated two time previously. So, to see the any sphincter loss from prior surgery, patient was planned for Anal manometry. The reporting of Anal Manometry of the patient has low squeeze pressure. It means patient have some sort of external anal sphincter loss. (see Figure-2)

Operative Procedure: Patient was nil per oral from 6 hours prior to surgery. Patient was made to lie in lithotomy position. Operated area was painted with betadine solution and wrap with sterile cut sheet. The injection lignocaine $2 \%$ with adrenaline was diluted with distilled water and infiltrated around fistulous opening and posteriorly at 6 o' Clock Position where the infected crypt was located. Now posterior window makes in between external \& internal sphincter and reach up to infected crypt from where proximal part of fistulous tract was intercepted from remaining distal part (see figure 3). Through posterior window have to clean \& drain the scrotal extension of fistulous tract. Then Guggul Ksharsutra (GKS) was placed in between intercepted part of fistulous tract to posterior window. The distal part of fistulous tract was curated with the help of curator from external opening \& haemostasis was achieved. Sterile packing was done with betadine followed by tight $\mathrm{T}$ - bandage applied.

\section{Post-Operative Procedure -}

- In post-operative period Patient have to advice to take daily Sitz bath with lukewarm water.

- Advice daily cleaning and dressing of wound with sterile betadine solution.

- Advice Powder Isabgoal 2TSF at bedtime after dinner for avoiding of constipation.

- Advice Tablet Shigru Guggul 2BD daily after meal.

- On $5^{\text {th }}$ day, Patient was discharged with advice that changing of Ksharsutra will be at every 7 days of interval as OPD procedure.

Table 1: Timeline of Treatment (in Week)

\begin{tabular}{|c|c|}
\hline Duration of treatment & Treatment (as OPD Procedure) \\
\hline 0 & Patient was discharged after IFTAK Procedure done in Operation Theatre \\
\hline $1^{\text {st }}$ Week & $1^{\text {st }}$ GKS (Guggul Kshar sutra) changed \& cleaning of wound with dressing done with Jatyadi tail \\
\hline $2^{\text {nd }}$ Week & $2^{\text {nd }}$ GKS (Guggul Kshar sutra) changed \& dressing of wound done with Jatyadi tail \\
\hline $3^{\text {rd }}$ Week & $3^{\text {rd }}$ GKS (Guggul Kshar sutra) changed \& widening of window with wound dressing done \\
\hline $4^{\text {th }}$ Week & $4^{\text {th }}$ GKS (Guggul Kshar sutra) changed \& widening of window with wound dressing done \\
\hline $5^{\text {th }}$ Week & $5^{\text {th }}$ GKS (Guggul Kshar sutra) changed \& dressing of wound done with Jatyadi tail \\
\hline $6^{\text {th }}$ Week & $6^{\text {th }}$ GKS (Guggul Kshar sutra) changed \& dressing of wound done with Jatyadi tail (see Figure-4) \\
\hline $7^{\text {th }}$ Week & $7^{\text {th }}$ GKS (Guggul Kshar sutra) changed \& dressing of wound done with Jatyadi tail \\
\hline $8^{\text {th }}$ Week & $8^{\text {th }}$ GKS (Guggul Kshar sutra) changed \& dressing of wound done with Jatyadi tail (see Figure-5) \\
\hline $9^{\text {th }}$ Week & Under Local Anaesthesia cut through was done and dressing with Jatyadi tail done \\
\hline $\begin{array}{l}\text { After } 15 \text { days of Cut } \\
\text { through }\end{array}$ & Wound is healed (see Figure-6 and 7) \\
\hline $\begin{array}{l}\text { After } 1 \text { month of cut } \\
\text { through }\end{array}$ & Wound is healed \\
\hline
\end{tabular}

Assessment- Assessment of symptoms were done on 5 parameters which are tabulated below-

Table-2: Assessment of Symptoms of Patient

\begin{tabular}{|l|l|l|l|l|l|}
\hline & Pain & Tenderness & Discharge & Induration & Incontinence \\
\hline $1^{\text {st }}$ Week & +++ & +++ & ++++ & +++ & - \\
\hline $2^{\text {nd }}$ Week & +++ & +++ & ++++ & ++ & - \\
\hline $3^{\text {rd }}$ Week & ++ & +++ & +++ & + & - \\
\hline $4^{\text {th }}$ Week & ++ & ++ & ++ & ++ & - \\
\hline
\end{tabular}




\begin{tabular}{|l|l|l|l|l|l|}
\hline $5^{\text {th }}$ Week & + & + & +++ & + & - \\
\hline $6^{\text {th }}$ Week & + & ++ & +++ & + & - \\
\hline $7^{\text {th }}$ Week & + & + & ++ & - & - \\
\hline $8^{\text {th }}$ Week & - & - & + & - & - \\
\hline $9^{\text {th }}$ Week & - & - & - & - & - \\
\hline $\begin{array}{l}\text { After } 15 \text { days } \\
\text { of Cut through }\end{array}$ & - & - & - & - \\
\hline $\begin{array}{l}\text { After 1 month } \\
\text { of cut through }\end{array}$ & - & - & - & - & \\
\hline
\end{tabular}

Complete recovery of the wound took place in about nine weeks of time. (Table-1)

\section{DISCUSSION}

Ksharsutra therapy for treatment of fistula in ano is an old, simple and effective therapy, which is described in Ayurveda. IFTAK is an modified technique of Ksharsutra which is mainly based on parks classification of fistula in ano ${ }^{[5]}$. IFTAK technique is effective in the management of complex and recurrent fistula in ano. This technique was practice in Banaras Hindu University since 2007 for complex fistula in ano ${ }^{[5]}$. Now this technique is more popular, effective, safe and cosmetically proved for management of complex \& recurrent fistula in ano. In this case Guggul Ksharsutra is used for treatment of complex fistula in ano, which is made up of Guggul (Commiphora mukul), Apamarg (Achyranthus aspera) kshar and Haridra (Curcuma longa). Guggul has itself property of antibacterial, anti-inflammatory and antifungal ${ }^{[6,7]}$. Guggul resin have the property of binding which is help full in the preparation of Ksharsutra. Curcuma longa has also possess the property of Antibacterial, antimicrobial, anti-inflammatory and anti-oxidant. ${ }^{[8]}$ In Ayurveda various types of kshar has been described. Apamarg kshar is one of them which have the property of excision, incision and scarification. Besides these properties, it also act like $\mathrm{Pa}$ chanah ( supparate the induration), Vilaynah ( to dissolve the swelling), Sodhanah (cleansing of dirty wound), Ropanah (help in healing of clean wound) and Shoshanah ( drying of discharge from wound). ${ }^{[9]}$ So GKS (Guggul Ksharsutra) is useful in the management of fistula in ano because it plays an combined effect like eradication of infected anal crypt (which is the main source of infection in fistula in ano), reduces the inflammation, cleansing and healing of fistulous tract. Above case, advice regular sitz bath with hot water,
Because Sitz baths with hot water had a greater analgesic effect because it reduces the internal anal sphincter pressure. ${ }^{[10,11]}$ It induces vasodilation which drawing blood into target tissue. Increased blood flow delivers more oxygen and nutrients \& removes the toxins (cells wastes). Ultimate hot water sitz bath for fistula in ano produces decrease muscles spasm, relax tense muscles, relieves pain, reduces burning, soothe irritation \& cleansing of wound. Shigru Guggul is also helpful in fistula in ano by the nutritious \& medicinal properties of Shigru (Moringa oliefera) like-antibacterial, anti-inflammatory, antimicrobial, analgesic effect and also rich in fibres and vitamic - $\mathrm{C}$, which also promote healing and overcome the constipation. ${ }^{[12,13]}$ Isabgoal ( psyllium) is an dietary fibre which act as bulk forming laxative and help to relieve the constipation.

\section{CONCLUSION}

The management of complex and recurrent fistula in ano is difficult and complicated because of its take time to complete healed and major part of sphincter involvement. But IFTAK (Interception of fistulous tract and application of Ksharsutra) is very effective for management of complex and recurrent fistula in ano. It is an ambulatory \& safe procedure, which have fast recovery rate and less or nil complication (chance to damage the sphincter and incontinence). This is minimal invasive technique for management of fistula in ano and offers better quality of life to the patients.

\section{REFERENCES}

1. Shastri A D., Ayurveda-tattva-sandipika, editor. Sushruta Samhita part-1, Sutra Sthana 33/4,5. varanasi: Chaukhambha Sanskrit Samsthan, 2002. p. 126. 
2. Shastri A D., Ayurveda-tattva-sandipika, editor. Sushruta Samhita part 1, Nidana Sthana, Ch 4, varanasi: Chaukhambha Sanskrit Samsthan, 2002. p. 244

3. "Anorectal Fistula". Merck Manual Consumer Version. Retrieved 2016-06-27.

4. Shastri A D., Ayurveda-tattva-sandipika, editor. Sushruta Samhita part 1, Chikitsa Sthana, Ch 8/24, 26 \&27, Varanasi: Chaukhambha Sanskrit Samsthan, 2002. p. $46-47$.

5. Sahu M, "A manual on Fistula in ano and Kshara Sutra therapy published by NRC Dept. of Shalyatantra, IMS, BHU, First edition 2015.

6. Kakrani, H.K., 1982. Physicochemical examination of seed oil from Commiphora mukul Hook ex Stocks. Indian Drugs, 19: 339-341.

7. Chaturvedi, G.N. and R.H. Singh, 1965. Experimental studies on the antiarthritic effect of certain indigenous drugs. Indian J. Med. Res., 53: 71-80. PubMed

8. Tilak J. C, Banerjee M, Mohan H, Devasagayam T. P. Antioxidant availability of turmeric in relation to its medicinal and culinary uses. Phytother Res. 2004; 18:798-804. [PubMed] [Reference list]

9. Priyavrat Sharma, Sushruta samhita, vol.II, Ist edi., 2000, Varanasi, Chaukhamba vishvabharati, p.no.114.

10. Cataldo P, Ellis CN, Gregorcyk S, Hyman N, Buie WD, Church J, et al. Practice parameters for the management of hemorrhoids (revised). Dis Colon Rectum. 2005; 48:189-94.

11. Lledó Matoses S. Cirugía colorrectal. Madrid: Ed. Arán; 2000

12. J.L. Rockwood, B.G. Anderson, D.A. Casamatta Potential uses of Moringa oleifera and an examination of antibiotic efficacy conferred by $\boldsymbol{M}$. oleifera seed and leaf extracts using crude extraction techniques available to underserved indigenous populations Int. J. Phytothearpy Res., 3 (2013), pp. 61-71

13. LakshmipriyaGopalakrishnan ${ }^{\mathrm{b}}$ KruthiDoriya ${ }^{\mathrm{a}}$ Devarai SanthoshKumar ${ }^{a}$ Moringa oleifera: A review on nutritive importance and its medicinal application, science direct https://doi.org/10.1016/j.fshw.2016.04.001

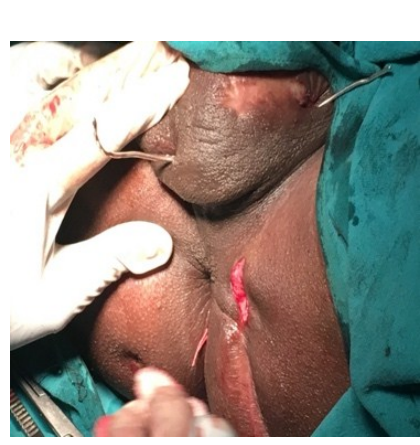

Figure-1

\section{ILLUSTRATIONS-}

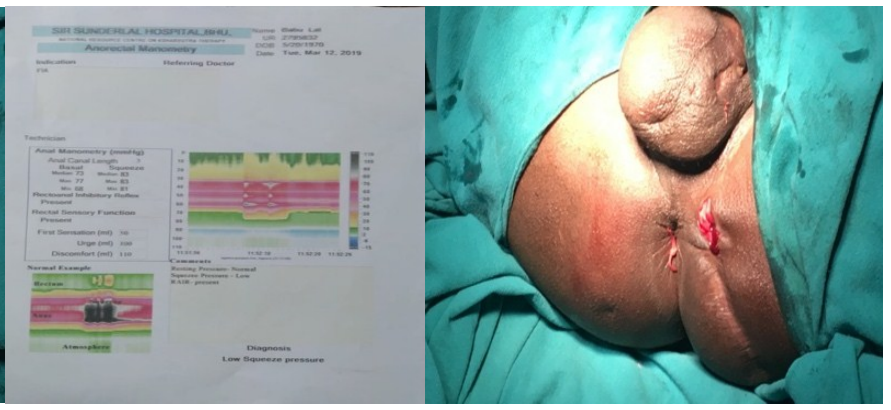

Figure-2

Figure-3

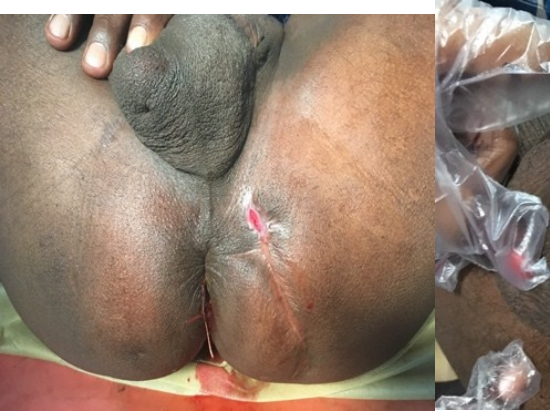

Figure-4

Figure-5

Figure-6

\section{Source of Support: Nil Conflict of Interest: None Declared}

How to cite this URL: Rashmi Gupta: Modified Ksharsutra Technique In Complex Fistula In Ano - A Case Study. International Ayurvedic Medical Journal \{online\} 2020 \{cited October, 2020\} Available from: http://www.iamj.in/posts/images/upload/4939_4943.pdf 